\title{
GYPSUM AND PHOSPHORUS IN IMPROVING BIOMETRIC AND NUTRITIONAL ATTRIBUTES OF SOYBEAN/SECOND SEASON CORN SUCCESSION $^{1}$
}

\author{
GUILHERME FILGUEIRAS SOARES ${ }^{2 *}$, SIMÉRIO CARLOS SILVA CRUZ ${ }^{3}$, TIAGO CAMILO DUARTE ${ }^{4}$, CARLA \\ GOMES MACHADO ${ }^{3}$, DARLY GERALDO DE SENA JUNIOR ${ }^{3}$
}

\begin{abstract}
The objective with this work was to evaluate the effect of the agricultural gypsum, associated with phosphate fertilization, on the nutrition, development and yield of soybean and corn in succession, under no-tillage system. The experiment was conducted at Universidade Federal de Goiás, Regional Jataí, in a randomized blocks design $5 \times 3$ factorial arrangement, with 4 replicates. The first factor consisted of the gypsum doses $(0,1,2,4$ and $8 \mathrm{Mg}$ ha- 1$)$ and the second the phosphorus doses $(0,50$ and $100 \%$ of the recommended dose). Leaf nutrient contents, leaf area index, SPAD index, dry plant mass, final plant population, one thousand grain mass and grain yield were evaluated in the crops. In the soybean, the number of pods was also obtained and in the corn the average ear length, number of rows per ear, number of grain per ear and number of ears. Phosphorus doses increase leaf $\mathrm{Mg}$ contents in soybean and corn. The application of gypsum reduces the $\mathrm{Mg}$ and $\mathrm{K}$ leaf contents and increases the $\mathrm{Ca}, \mathrm{S}$, and $\mathrm{Mn}$ contents in the two cultures. Gypsum provides increases in the SPAD index in soybean plants. The unbalance of the $\mathrm{N} / \mathrm{K}$ ratio in corn leaves, provided by the increase of the gypsum doses, reduces the leaf area of this crop. Doses of P and gypsum do not influence the yield of soybeans and maize.
\end{abstract}

Keywords: Glycine max (L.). Zea mays. Gypsum. Phosphate applications.

\section{GESSO E FÓSFORO NA MELHORIA DOS ATRIBUTOS BIOMÉTRICOS E NUTRICIONAIS DA SUCESSÃO SOJA/MILHO SAFRINHA}

RESUMO - Objetivou-se com este trabalho avaliar o efeito do gesso agrícola associado à adubação fosfatada, sobre a nutrição, desenvolvimento e produtividadeda da soja e do milho em sucessão, sob sistema plantio direto. O experimento foi conduzido na Universidade Federal de Goiás, Regional Jataí, com delineamento experimental constituído de 15 tratamentos estabelecidos em blocos casualizados em esquema fatorial $5 \times 3$, com 4 repetições. O primeiro fator correspondeu as doses de gesso $\left(0,1,2,4\right.$ e $\left.8 \mathrm{Mg} \mathrm{ha}^{-1}\right)$ e o segundo fator às doses de fósforo $(0,50$ e $100 \%$ da dose recomendada). Foram avaliados nas culturas os teores foliares de nutrientes, índice de área foliar, índice SPAD, massa de plantas secas, população final de plantas, massa de mil grãos e produtividade de grãos. Ainda, na soja foi obtido o número de vagens e no milho o comprimento médio de espiga, número de fileiras de grãos por espiga, número de grãos por espiga e o número de espigas. As doses de fósforo aumentam os teores foliares de $\mathrm{Mg}$ na soja e no milho. A aplicação de gesso reduz os teores de $\mathrm{Mg}$ e $\mathrm{K}$ e aumentam os de $\mathrm{Ca}, \mathrm{S}$ e $\mathrm{Mn}$ nas duas culturas. $\mathrm{O}$ gesso proporciona incrementos no índice SPAD em plantas de soja. O desbalanço da relação N/K nas folhas de milho, proporcionadas pelo incremento das doses de gesso, reduz a área foliar desta cultura. Doses de P e de Gesso não influenciam a produtividade da soja e do milho safrinha.

Palavras-chave: Glycine max (L.). Zea mays. Gessagem. Fosfatagem.

\footnotetext{
"Corresponding author

${ }^{1}$ Received for publication in $10 / 28 / 2016$; accepted in $05 / 11 / 2017$.

Paper extracted from the master's dissertation of the first author.

${ }^{2}$ Universidade de Brasília, Brasília, DF, Brazil; soaresgf30@gmail.com.

${ }^{3}$ Universidade Federal de Goiás, Jataí, GO, Brazil; simerio_cruz@yahoo.com.br, carlagomesmachado@gmail.com, darly.sena@gmail.com.

${ }^{4}$ Universidade Federal de Goiás, Goiânia, GO, Brazil; tiagocamiloduarte@gmail.com.
} 


\section{INTRODUCTION}

As widely known, the productive potential of the cerrado soils is only reached due to the use of limestone that corresponds to an agricultural input that promotes $\mathrm{pH}$ correction and reduces soil toxic aluminum. However, the sole use of this correction practice is strongly questioned since superficial liming without soil revolving (as recommended in the no-tillage system) limits the corrective effect of limestone to the superficial layers (CAIRES et al., 2003). This situation requires the use of soil conditioners, such as agricultural gypsum, to neutralize aluminum and provide calcium in depth (OLIVEIRA et al., 2009; ZANDONÁ et al., 2015). The high levels of $\mathrm{Al}^{+3}$ and the reduction of exchangeable bases in the deeper soil layers was indicated as limiting parameters of root development and consequently a decrease in crop yield (MATTIELLO et al., 2008; NORA et al., 2014).

Agricultural gypsum is a by-product of the phosphate fertilizer industry that mainly contains calcium sulfate and small concentrations of $\mathrm{P}$ and $\mathrm{F}$ (CAIRES et al., 2003; SÁVIO et al., 2011). It is used as a source of $\mathrm{Ca}^{2+}$ and as a soil subsurface conditioner to reduce the toxicity of $\mathrm{Al}^{3+}$ (BROCH et al., 2008; OLIVEIRA et al., 2009).

The conditions that can be expected with the positive effects of gypsum application on crop production continue to be unclear (CAIRES et al., 2011). It is important to highlight that the use of agricultural gypsum is not always associated with high levels of $\mathrm{Al}^{3+}$ in the subsoil. This is because gypsum is used to supply calcium in conditions of $\mathrm{Al}^{3+}$ and $\mathrm{Ca}^{2+}$ low concentrations, and this provides better root growth in depth and allows for the increased efficiency of the absorption of water and nutrients (RITCHEY; SILVA; COSTA, 1982; SORATTO; CRUSCIOL, 2008).

In studies by Zandoná et al. (2015), gypsum application allowed better soybean root development in a no-tillage system and favored water absorption from deeper soil layers and provided greater tolerance to the water deficit.
As previously reported, responses to gypsum application were more frequent with water deficit. However, increases in corn yield by using gypsum without water deficit were observed in studies by Caires et al. (2011) and Zandoná et al. (2015). Nevertheless, several studies did not indicate responses to gypsum applied in soybeans (CAIRES et al., 1998; 1999; 2003; NEIS et al., 2010; RAMPIM et al., 2011; MODA et al., 2013).

Thus, it is hypothesized that the increased development of the crop root system provided by agricultural gypsum as frequently reported in the literature increases the absorption efficiency of plant phosphorus due to the increased volume of soil explored since the main factors that affect phosphorus absorption by the crops correspond to the root growth rate, $\mathrm{P}$ concentration in the soil solution, and root mean radius (ROSOLEM; ASSIS; SANTIAGO, 1994).

Given the fore-mentioned points, the objective of this study involves evaluating the effect of agricultural gypsum associated with phosphate fertilization on the nutrition, development, and yield of soybeans and second season corn in succession under a no-tillage system.

\section{MATERIAL AND METHODS}

The experiment was performed in Jataí, GO, growing season 2014/2015, at the Universidade Federal de Goiás - Regional Jataí experimental area with coordinates corresponding to $17^{\circ} 55^{\prime} 32^{\prime \prime} \mathrm{S}$ and $51^{\circ} 42^{\prime} 32^{\prime \prime} \mathrm{W}$, and altitude of $685 \mathrm{~m}$. The soil of the area was classified as LATOSSOLO VERMELHO Distroférrico (LVdf) by using the Brazilian soil classification system with a clayey texture (EMBRAPA, 2006). The predominant climate in the region corresponds to the Aw type based on the Köppen classification that is typical of the savannas with two well defined seasons, namely a dry and cold season (autumn and winter) and a hot and humid season(spring and summer).

The meteorological data collected during the experiment conduction are presented in Figure 1.

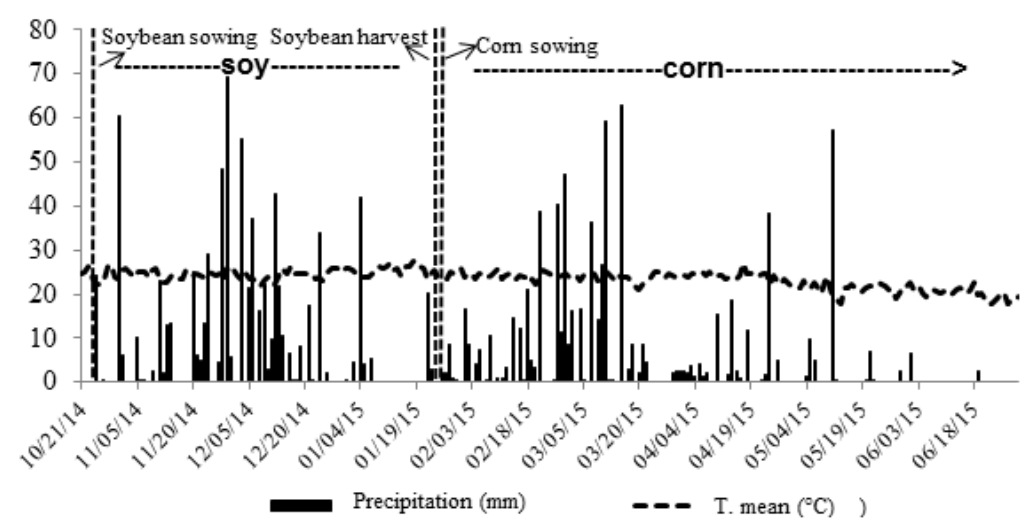

Figure 1. Rainfall $(\mathrm{mm})$ and mean temperature $\left({ }^{\circ} \mathrm{C}\right)$ in the experimental area from October 2014 to June 2015. 
Soil samples were collected at depths corresponding to 0 to $20 \mathrm{~cm}$ and 20 to $40 \mathrm{~cm}$ (Table 1) to enable soil correction, determination of crop fertilization levels, and chemical and textural characterization of the soil in the experimental area.

The experiment consisted of 15 treatments established in a $5 \times 3$ factorial scheme randomized blocks design with four replications. Each plot corresponded to $11.25 \mathrm{~m}^{2}(2.25 \times 5.00 \mathrm{~m})$, and the useful area corresponded to the three central lines excluding $1 \mathrm{~m}$ from each end. The first factor corresponded to the gypsum doses $\left(0 \mathrm{Mg} \mathrm{ha}^{-1}\right.$, $1 \mathrm{Mg} \mathrm{ha}^{-1}, 2 \mathrm{Mg} \mathrm{ha}^{-1}, 4 \mathrm{Mg} \mathrm{ha}^{-1}$ and $\left.8 \mathrm{Mg} \mathrm{ha}^{-1}\right)$ and the second factor corresponded to the phosphorus doses $\left(0 \mathrm{~kg} \mathrm{ha}^{-1}, 40 \mathrm{~kg} \mathrm{ha}^{-1}\right.$, and $\left.80 \mathrm{~kg} \mathrm{ha}^{-1}\right)$. These $\mathrm{P}_{2} \mathrm{O}_{5}$ doses represent $0 \%, 50 \%$, and $100 \%$ of the recommended dose by Sousa and Lobato (2004).

Soil correction was performed with 3.0 $\mathrm{Mg} \mathrm{ha}^{-1}$ of dolomitic limestone $($ RTNP $=85 \%)$ that was applied in the area three months prior to the soybean crop seeding with a gravitational metering system and gravity distribution equipment without incorporation. The gypsum was manually and superficially applied 30 days after limestone in the area in each treatment dose. Agricultural gypsum samples were collected for chemical characterization by using the methodology described in the manual of official analytical methods (Table 2).

Table 1. Soil characterization of the chemical and textural experimental area at depths of $0-20 \mathrm{~cm}$ and $20-40 \mathrm{~cm}$ prior to the experiment.

\begin{tabular}{|c|c|c|c|c|c|c|c|c|c|c|c|}
\hline \multicolumn{12}{|c|}{ Property } \\
\hline \multirow{2}{*}{$\begin{array}{l}\text { Depth. } \\
(\mathrm{cm})\end{array}$} & \multirow{2}{*}{$\begin{array}{c}\mathrm{pH} \\
\mathrm{CaCl}_{2}\end{array}$} & \multirow{2}{*}{$\begin{array}{l}\text { (g kg-1) } \\
\text { O.M. }\end{array}$} & \multirow{2}{*}{\multicolumn{2}{|c|}{$\begin{array}{c}\left(\mathrm{mg} \mathrm{dm}^{-3}\right) \\
\mathrm{P} \text { (mel.) }\end{array}$}} & \multicolumn{6}{|c|}{$\left(\mathrm{cmol}_{\mathrm{c}} \mathrm{dm}^{-3}\right)$} & \multirow{2}{*}{$\mathrm{V} \%$} \\
\hline & & & & & $\mathrm{K}$ & $\mathrm{Ca}$ & $\mathrm{Mg}$ & $\mathrm{Al}$ & $\mathrm{H}+\mathrm{Al}$ & CEC & \\
\hline $0-20$ & 5.2 & 45.2 & & 8.5 & 0.16 & 2.26 & 1.37 & 0.10 & 5.1 & 8.9 & 42.6 \\
\hline $20-40$ & 5.3 & 36.1 & & 4.3 & 0.13 & 1.75 & 0.95 & 0.07 & 4.3 & 7.1 & 39.9 \\
\hline Depth. & $\mathrm{S}$ & $\mathrm{Fe}$ & $\mathrm{Mn}$ & $\mathrm{Zn}$ & $\mathrm{Cu}$ & $\mathrm{Na}$ & \multirow{2}{*}{\multicolumn{2}{|c|}{$\mathrm{Al}$ sat. $(\%)$}} & \multicolumn{3}{|c|}{ Texture $\left(\mathrm{g} \mathrm{dm}^{-3}\right)$} \\
\hline$(\mathrm{cm})$ & & \multicolumn{5}{|c|}{ 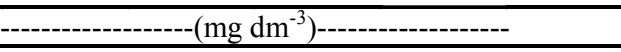 } & & & Clay & Sand & Silt \\
\hline $0-20$ & 13.8 & 28.0 & 29.5 & 3.4 & 6.6 & 2.7 & & & \multirow{2}{*}{585} & \multirow{2}{*}{240} & \multirow{2}{*}{175} \\
\hline $20-40$ & 30.6 & 40.0 & 25.0 & 7.7 & 7.3 & 0.9 & & & & & \\
\hline
\end{tabular}

Table 2. Chemical characterization of agricultural gypsum.

\begin{tabular}{|c|c|c|c|c|c|c|}
\hline $\mathrm{Ca}$ & $\mathrm{S}$ & $\mathrm{P}_{2} \mathrm{O}_{5}$ & $\mathrm{Cu}$ & $\mathrm{Fe}$ & $\mathrm{Mn}$ & $\mathrm{Zn}$ \\
\hline 2356 & 18.64 & 0.70 & 0.014 & 0.25 & 0.012 & 0.005 \\
\hline
\end{tabular}

According to Sousa and Lobato (2004), the P and $\mathrm{K}$ recommended doses corresponded to $80 \mathrm{~kg} \mathrm{ha}^{-1}$ of $\mathrm{P}_{2} \mathrm{O}_{5}$ and $80 \mathrm{~kg} \mathrm{ha}^{-1}$ of $\mathrm{K}_{2} \mathrm{O}$. Triple super phosphate and potassium chloride were used as sources for supplying $\mathrm{P}$ and $\mathrm{K}$, respectively. The phosphorus doses corresponding to each treatment for the soybean crop were distributed in the planting furrow during seeding. Potassium was manually distributed in each plot on the soil surface and corresponded to $60 \mathrm{~kg} \mathrm{ha}^{-1}$ of $\mathrm{K}_{2} \mathrm{O} 15$ days after sowing and the remaining $20 \mathrm{~kg} \mathrm{ha}^{-1} 10$ days after the previous application .

The soybean sowing was performed on October 24, 2014 by using a 5-row tractor seeder with an interval of $0.5 \mathrm{~m}$ between rows and 22 seeds planted per meter of the cultivar Anta 82 RR (medium cycle, 112 to 114 days and semi-determined growth habit).

The second season corn was seeded on February 24, 2015 after the soybean harvest with the same seeder and distributed 2.8 seeds per meter of the hybrid 2B587 PW RR (early cycle, 138 days).

According to Sousa and Lobato (2004), the recommended doses of NPK to the second season corn crop corresponded to $150 \mathrm{~kg} \mathrm{ha}^{-1}$ of $\mathrm{N}$ and $80 \mathrm{~kg} \mathrm{ha}^{-1}$ of $\mathrm{P}_{2} \mathrm{O}_{5}$ and $\mathrm{K}_{2} \mathrm{O}$. The sources of these nutrients corresponded to urea, monoammonium phosphate, and potassium chloride, respectively. The phosphorous doses, corresponding to each treatment for the corn crop were distributed at seeding in the planting furrow. Nitrogen and potassium were superficially manually distributed in each plot 15 days after sowing. Leaf samples were collected in the soybean crop at the beginning of flowering 27 days after emergence (DAE) and the samples were collected at full flowering for the corn crop, and this corresponded to $60 \mathrm{DAE}$. The dry material was submitted to chemical analysis to determine the $\mathrm{N}, \mathrm{P}, \mathrm{K}, \mathrm{Ca}, \mathrm{Mg}, \mathrm{S}, \mathrm{Zn}, \mathrm{Mn}, \mathrm{Al}, \mathrm{B}, \mathrm{Cu}$, and $\mathrm{Fe}$ contents by following the methodology described in a study by Malavolta, Vitti and Oliveira (1997).

With respect to the flowering of the two crops, the SPAD index, leaf area index, and dry plant mass were also evaluated. The SPAD index was determined by using a chlorophyll meter (ClorofiLOG ${ }^{\circledR}$ model CFL 1030) that was operated based on the manufacturer's instructions. The leaf area index was obtained with an Accupar ${ }^{\circledR}$ ceptometer that measured the active photosynthetically radiation under and above the canopy to determine the LAI with five readings in the useful area of each plot. The dry plant mass was 
determined by cutting five plants close to the soil and subsequently drying the same in an air circulation oven by maintaining a temperature in the range of $65^{\circ} \mathrm{C}$ to $70^{\circ} \mathrm{C}$.

The following components were evaluated at the soybean harvest: final plant population, number of pods, one thousand grains mass, weighting eight replicates of 100 seeds, and grain yield corrected to $13 \%$ moisture. With respect to the corn, the final plant population, number of ears, number of grain rows per ear, number of grains per ear, one thousand grains mass, and grain yield corrected to $13 \%$ moisture were determined.

The data were submitted to variance analysis at $5 \%$ and $1 \%$ of probability by the $\mathrm{F}$ test, and the Tukey test was used to compared the means referring to the $\mathrm{P}$ doses. The gypsum doses data were submitted to regression analysis calculated for linear and quadratic equations with an acceptance level corresponding to a significance level of $5 \%$ of probability with the F test.

\section{RESULTS AND DISCUSSION}

With respect to the soybean crop, significant interaction was not observed between the doses of phosphorus and gypsum for any of the evaluated variables. Only the $\mathrm{Mg}$ leaf content varied based on the phosphorus doses (Table 3). Additionally, the $\mathrm{Mg}$ increased and corresponded to $3.53 \mathrm{~g} \mathrm{~kg}^{-1}$ in the treatment with the recommended dose of $\mathrm{P}$ corresponding to $80 \mathrm{~kg} \mathrm{ha}^{-1}$. The values corresponded to $3.45 \mathrm{~g} \mathrm{~kg}^{-1}$ and $3.28 \mathrm{~g} \mathrm{~kg}^{-1}$ when the $\mathrm{P}$ dose was reduced to $40 \mathrm{~kg} \mathrm{ha}^{-1}$ and $0 \mathrm{~kg} \mathrm{ha}^{-1}$, respectively.

Table 3. Summary of variance analysis: block, gypsum, phosphorus, and its interactions for leaf analysis as determined in the full flowering stage of the soybean crop.

\begin{tabular}{|c|c|c|c|c|c|c|c|c|c|c|}
\hline Variation Causes & $\mathrm{N}$ & $\mathrm{P}$ & $\mathrm{K}$ & $\mathrm{Ca}$ & $\mathrm{Mg}$ & $\mathrm{S}$ & $\mathrm{Zn}$ & $\mathrm{Mn}$ & $\mathrm{Fe}$ & $\mathrm{Al}$ \\
\hline Block & $10.11^{* *}$ & $8.42^{* * *}$ & $1.71^{\mathrm{ns}}$ & $1.69^{\mathrm{ns}}$ & $2.37^{\mathrm{ns}}$ & $4.23^{\mathrm{ns}}$ & $9.88^{* *}$ & $8.03^{* * *}$ & $1.60^{\mathrm{ns}}$ & $3.68^{*}$ \\
\hline Gypsum & $1.32^{\mathrm{ns}}$ & $1.66^{\mathrm{ns}}$ & $5.13^{* *}$ & $17.85^{* *}$ & $16.67^{* *}$ & $4.86^{* *}$ & $8.27^{* *}$ & $2.84^{* *}$ & $1.57^{\mathrm{ns}}$ & $1.57^{\mathrm{ns}}$ \\
\hline Phosphorus & $0.37^{\mathrm{ns}}$ & $1.02^{\mathrm{ns}}$ & $2.99^{\mathrm{ns}}$ & $2.77^{\mathrm{ns}}$ & $3.89^{*}$ & $0.11^{\mathrm{ns}}$ & $0.90^{\mathrm{ns}}$ & $0.49^{\mathrm{ns}}$ & $1.00^{\mathrm{ns}}$ & $0.65^{\mathrm{ns}}$ \\
\hline Gypsum x Phosphorus & $1.44^{\mathrm{ns}}$ & $0.37^{\mathrm{ns}}$ & $0.80^{\mathrm{ns}}$ & $0.67^{\mathrm{ns}}$ & $0.48^{\mathrm{ns}}$ & $1.52^{\mathrm{ns}}$ & $1.38^{\mathrm{ns}}$ & $0.42^{\mathrm{ns}}$ & $1.15^{\mathrm{ns}}$ & $1.69^{\mathrm{ns}}$ \\
\hline \multicolumn{11}{|c|}{ Polynomial Regression } \\
\hline Equation & $\mathrm{N}$ & $\mathrm{P}$ & $\mathrm{K}$ & $\mathrm{Ca}$ & $\mathrm{Mg}$ & $\mathrm{S}$ & $\mathrm{Zn}$ & $\mathrm{Mn}$ & $\mathrm{Fe}$ & $\mathrm{Al}$ \\
\hline Linear & $2.00^{\mathrm{ns}}$ & $2.20^{\mathrm{ns}}$ & $13.12^{* *}$ & $70.96^{* *}$ & $65.67^{* *}$ & $14.71^{* *}$ & $30.22^{2}$ & 8.67 & $0.51^{\mathrm{ns}}$ & $2.47^{\mathrm{ns}}$ \\
\hline Quadratic & $0.15^{\mathrm{ns}}$ & $0.01^{\mathrm{ns}}$ & $0.27^{\mathrm{ns}}$ & $0.02^{\mathrm{ns}}$ & $0.01^{\mathrm{ns}}$ & $2.11^{\mathrm{ns}}$ & $2.81^{\mathrm{ns}}$ & $0.23^{\mathrm{ns}}$ & $2.01^{\mathrm{ns}}$ & $1.59^{\mathrm{ns}}$ \\
\hline
\end{tabular}

**Significant at $1 \%$ probability $(\mathrm{p}<0.01)$. ${ }^{*}$ Significant at $5 \%$ probability $(0.01=<\mathrm{p}<0.05)$. ${ }^{\mathrm{ns}}$ not significant $(\mathrm{p}>=0.05)$.

A reason for the increase in the $\mathrm{Mg}$ leaves contents with increases in the doses of $\mathrm{P}$ is that the $\mathrm{P}$ availability is an important factor for the mobilization, absorption, and translocation of $\mathrm{Mg}$ to the plant (ZHONG; SCHOBERT; KOMOR, 1993). Thus, an application of $100 \%$ of the recommended $\mathrm{P}$ dose increased the access of the plant to the nutrient and consequently increased the absorption of $\mathrm{Mg}$ when compared to the lower doses of P.

With respect to the gypsum dose variation factor, the $\mathrm{K}, \mathrm{Ca}, \mathrm{Mg}$, and $\mathrm{S}$ macronutrients contents were adjusted to a linear regression equation (Table 3). The $\mathrm{Mg}$ and $\mathrm{K}$ contents decreased with increases in the gypsum doses (Figure 2A and 2B) and indicated that the application of high doses of gypsum reduces the concentration of these ions in soybean leaf at levels below those that are considered critical (MARTINEZ; CARVALHO; SOUZA, 1999).

A reason for these results is related to the occurrence of competitive inhibition between $\mathrm{K}$ and $\mathrm{Mg}$ (MALAVOLTA; VITTI; OLIVEIRA, 1997) in relation to the elevation of $\mathrm{Ca}$ levels in soybean plant tissue (Figure 2C). This occurs when increases in ion concentration causes a partial and reversible decrease in the absorption of another element that combines with the same charger site to cross the membrane (MALAVOLTA, 2006). This behavior may also be related to the leaching of these nutrients in the soil profile due to the use of high gypsum doses as observed in studies by Caires et al. (1999), Caires et al. (2003), and Nava et al. (2012).

The $\mathrm{Ca}$ and $\mathrm{S}$ contents increased with increases in the gypsum doses (Figure 2C and 2D). The increase in $\mathrm{Ca}$ and $\mathrm{S}$ in the leaf contents was expected since this corrective is a source of these nutrients. Increases in $\mathrm{Ca}$ and $\mathrm{S}$ concentrations in soybean leaves were also observed in other studies (CAIRES et al., 2003; CAIRES; JORIS; CHURKA, 2011; GELAIN et al., 2011).

The $\mathrm{Zn}$ and $\mathrm{Mn}$ leaf contents also increased with increases in the gypsum doses (Figure 2E and $2 \mathrm{~F})$. This increase is related to the presence of these micronutrients in gypsum (Table 2) since significant amounts of these micronutrients are added when high doses of the fertilizer are applied.

The reduction in the $\mathrm{P}_{2} \mathrm{O}_{5}$ dose did not influence vegetative development and grain yield of the soybean crop (Table 4). 

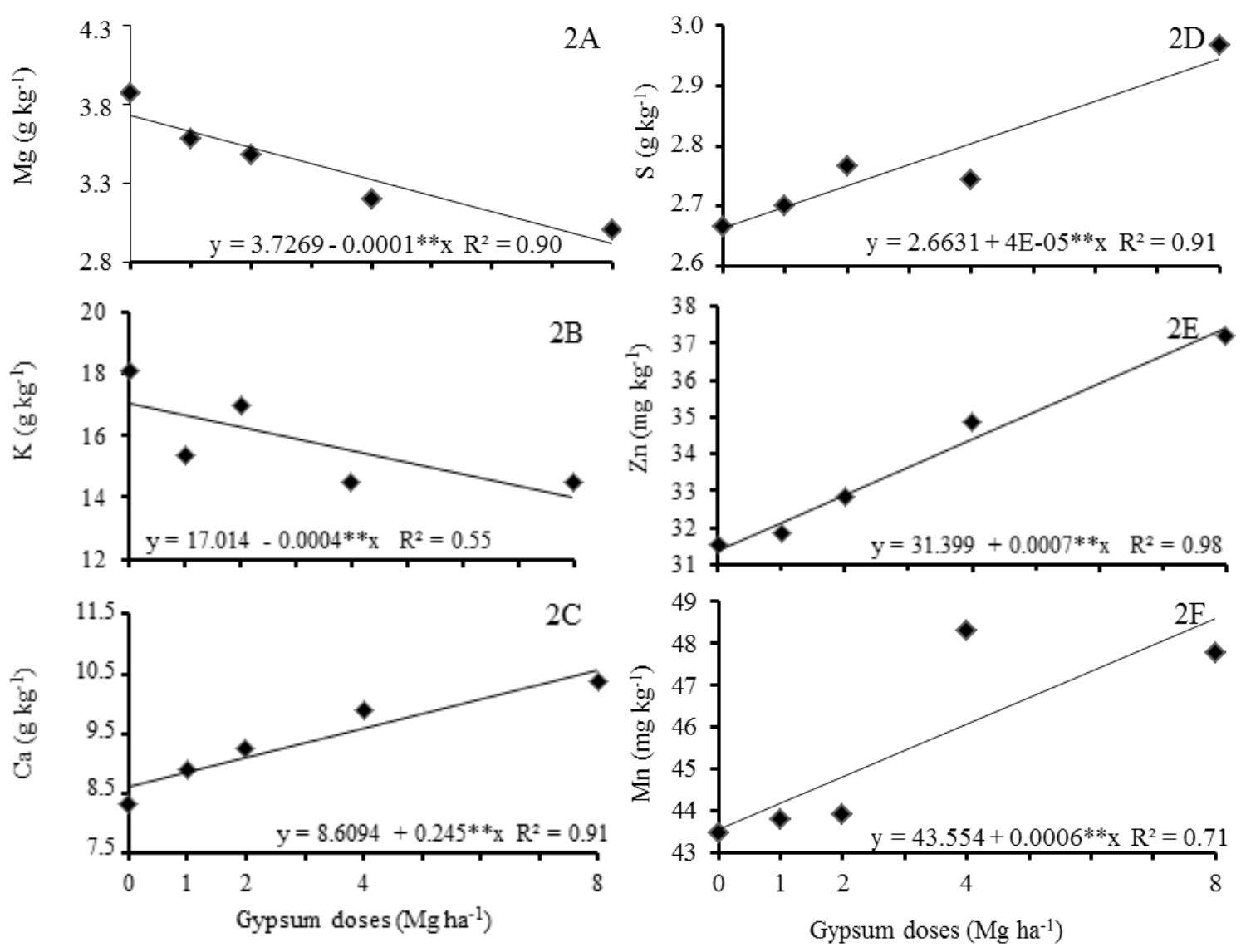

Figure 2. Leaf contents $\mathrm{Mg}(\mathrm{A}) ; \mathrm{K}(\mathrm{B}) ; \mathrm{Ca}(\mathrm{C}) ; \mathrm{S}(\mathrm{D}) ; \mathrm{Zn}(\mathrm{E})$; and $\mathrm{Mn}(\mathrm{F})$ based on the gypsum doses. (**Significant at $1 \%$ probability).

Table 4. Summary of variance analysis: block, gypsum, phosphorus, and its interactions for leaf area index (LAI), SPAD index (SPAD), dry plant mass (DM), final plant population (PP), number of pods (NP), thousand grain mass (TGM), and soybean grain yield (YIE).

\begin{tabular}{|c|c|c|c|c|c|c|c|}
\hline Variation Causes & LAI & SPAD & $\mathrm{DM}$ & PP & NP & TGM & YIE \\
\hline Block & $3.94^{*}$ & $10.12^{* *}$ & $4.68^{* *}$ & $5.83^{* *}$ & $4.42^{* *}$ & $2.37^{\mathrm{ns}}$ & $1.62^{\mathrm{ns}}$ \\
\hline Gypsum & $0.58^{\mathrm{ns}}$ & $3.44^{* *}$ & $0.19^{\mathrm{ns}}$ & $0.33^{\mathrm{ns}}$ & $1.68^{\mathrm{ns}}$ & $2.04^{\mathrm{ns}}$ & $1.38^{\mathrm{ns}}$ \\
\hline Phosphorus & $0.36^{\mathrm{ns}}$ & $0.09^{\mathrm{ns}}$ & $0.31^{\mathrm{ns}}$ & $1.25^{\mathrm{ns}}$ & $0.84^{\mathrm{ns}}$ & $0.06^{\mathrm{ns}}$ & $0.78^{\mathrm{ns}}$ \\
\hline Gypsum x Phosphorus & $0.80^{\mathrm{ns}}$ & $0.44^{\mathrm{ns}}$ & $0.78^{\mathrm{ns}}$ & $0.29^{\mathrm{ns}}$ & $0.44^{\mathrm{ns}}$ & $0.77^{\mathrm{ns}}$ & $1.84^{\mathrm{ns}}$ \\
\hline \multicolumn{8}{|c|}{ Polynomial Regression } \\
\hline Equations & IAF & SPAD & MS & PP & NV & PMG & PROD \\
\hline Linear & $0.10^{\mathrm{ns}}$ & $10.35^{\text {** }}$ & $0.04^{\mathrm{ns}}$ & $0.23^{\mathrm{ns}}$ & $0.43^{\mathrm{ns}}$ & $0.27^{\mathrm{ns}}$ & $0.01^{\mathrm{ns}}$ \\
\hline Quadratic & $0.86^{\mathrm{ns}}$ & $3.24^{\mathrm{ns}}$ & $0.51^{\mathrm{ns}}$ & $0.26^{\mathrm{ns}}$ & $2.91^{\mathrm{ns}}$ & $4.35^{\mathrm{ns}}$ & $2.37^{\mathrm{ns}}$ \\
\hline Phosphorus & IAF & SPAD & MS & PP & NV & MMG & PROD \\
\hline $0 \%$ & $2.67 \mathrm{a}$ & $42.19 \mathrm{a}$ & $32.23 \mathrm{a}$ & $56.45 \mathrm{a}$ & $27.13 \mathrm{a}$ & $11.37 \mathrm{a}$ & $3187.33 \mathrm{a}$ \\
\hline $50 \%$ & $2.61 \mathrm{a}$ & $42.29 \mathrm{a}$ & $31.78 \mathrm{a}$ & $54.55 \mathrm{a}$ & $28.78 \mathrm{a}$ & $11.31 \mathrm{a}$ & $2993.30 \mathrm{a}$ \\
\hline $100 \%$ & $2.49 \mathrm{a}$ & $42.31 \mathrm{a}$ & $30.75 \mathrm{a}$ & $53.45 \mathrm{a}$ & $27.63 \mathrm{a}$ & $11.30 \mathrm{a}$ & $3097.49 \mathrm{a}$ \\
\hline MSD & 0.51 & 0.72 & 4.69 & 4.66 & 3.16 & 0.53 & 378.13 \\
\hline $\mathrm{VC}$ & 25.88 & 2.21 & 19.33 & 11.08 & 14.80 & 6.04 & 15.92 \\
\hline
\end{tabular}

**Significant at $1 \%$ probability $(\mathrm{p}<0.01)$. ${ }^{*}$ Significant at $5 \%$ probability $(0.01=<\mathrm{p}<0.05)$. ${ }^{\mathrm{ns}}$ not significant $(\mathrm{p}>=0.05)$.

The lack of response of phosphate fertilization potentially occurred due to the adequate $\mathrm{P}$ soil levels at the time of sowing the soybean crop. Thus, the soil capacity factor provided the nutrient to the soil solution and made it available to the plants. When phosphorus levels exceeded the critical level, the probability of crop response is very low or absent
(PAVINATO; CERETTA, 2004). The critical level for clay soils on the Cerrado region corresponds to $8 \mathrm{mg} \mathrm{dm}^{-3}$ for rainfed systems (SOUSA; LOBATO, 2004). The $P$ level in $0-20 \mathrm{~cm}$ of a soil layer in the experimental area prior to the experiment corresponded to $8.5 \mathrm{mg} \mathrm{dm}^{-3}$, and this justifies the lack of response of the soybean crop to phosphate 
fertilization.

With respect to gypsum doses, it was possible to adjust a positive linear regression equation for the SPAD index of soybean plants (Figure 3). The increase based on the gypsum doses is associated with the increased addition of $\mathrm{S}$ to the soil that increases its availability and absorption in plants. The SPAD index increased because the nutrient participates in chlorophyll synthesis as a component of ferrodoxins and thioredoxins (MALAVOLTA, 2006).

The gypsum doses did not influence other variables including soybean crop yield. Similar results were found in studies by Caires et al. (1999), Neis et al. (2010), Caires, Joris and Churka (2011), Rampim et al. (2011), Moda et al. (2013), and Pauletti et al. (2014).

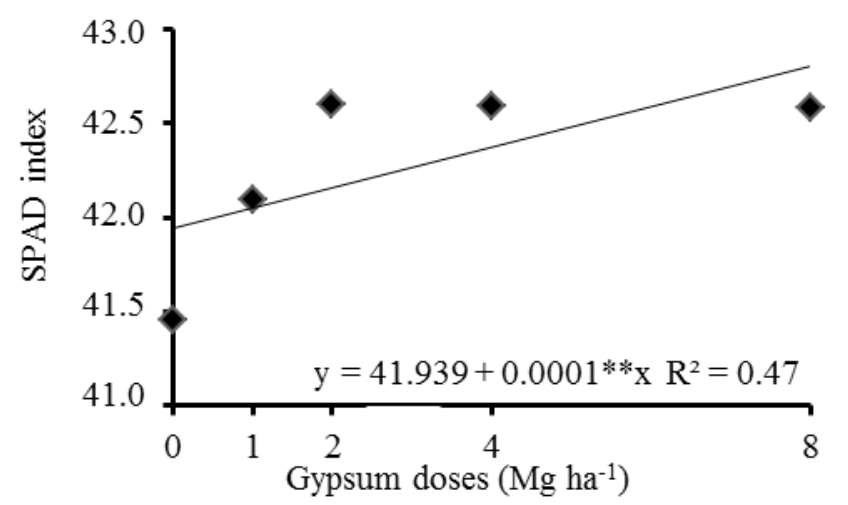

Figure 3. SPAD index based on the gypsum doses. (**Significant at $1 \%$ probability).

Interaction between gypsum and phosphorous was not observed in the macro and micronutrients contents for the corn crop (Table 5). The P doses were evaluated in isolation, and it was observed that they influence the $\mathrm{Mg}$ and $\mathrm{Zn}$ leaf contents (Table 5). The results verified that the $\mathrm{Mg}$ levels in corn presented behavior similar to that observed in the soybean crop. The $\mathrm{Mg}$ contents increased ( $2.29 \mathrm{~g} \mathrm{~kg}^{-1}$ ) in the treatment with the recommended doses of $\mathrm{P}\left(80 \mathrm{~kg} \mathrm{ha}^{-1}\right.$ of $\left.\mathrm{P}_{2} \mathrm{O}_{5}\right)$. A decrease in the doses led to values of $2.13 \mathrm{~g} \mathrm{~kg}^{-1}$ and $2.10 \mathrm{~g} \mathrm{~kg}^{-1}$ with respect to the $40 \mathrm{~kg} \mathrm{ha}^{-1}$ and $0 \mathrm{~kg} \mathrm{ha}^{-1}$ doses, respectively. An explanation for this behavior is the same as that used for soybean crop in which higher $\mathrm{Mg}$ levels in corn leaves were observed in the plots that received phosphate fertilization due to increased availability of $\mathrm{P}$ to the plants since phosphorous is an important factor for mobilization, absorption, and translocation of $\mathrm{Mg}$ into a plant (ZHONG; SCHOBERT; KOMOR, 1993).

The $\mathrm{Zn}$ corn leaf contents responded negatively to the $\mathrm{P}$ doses, and thus the $\mathrm{Zn}$ contents decreased $\left(20.65 \mathrm{mg} \mathrm{kg}^{-1}\right)$ in the treatment in which $80 \mathrm{~kg} \mathrm{ha}^{-1}$ of the nutrient were applied. Values increased and corresponded to 21.23 and $22.21 \mathrm{mg} \mathrm{kg}^{-1}$ when the dose was halved and when the dose was absent, respectively. The use of high $\mathrm{P}$ doses could impair the assimilation of the $\mathrm{Zn}$ micronutrient (MUNER et al., 2011) wherein the deficiency is relatively common mainly due to the low amount in the cerrado soils (VENDRAME et al., 2007).

Table 5. Summary of variance analysis: block, gypsum, phosphorus, and its interactions for leaf macro nutrients determined at the full flowering stage of the corn.

\begin{tabular}{|c|c|c|c|c|c|c|c|c|c|c|}
\hline Variation Causes & $\mathrm{N}$ & $\mathrm{P}$ & $\mathrm{K}$ & $\mathrm{Ca}$ & $\mathrm{Mg}$ & $\mathrm{S}$ & $\mathrm{Zn}$ & $\mathrm{Mn}$ & $\mathrm{Fe}$ & $\mathrm{Al}$ \\
\hline Block & $2.69^{\mathrm{ns}}$ & $0.42^{\mathrm{ns}}$ & $0.87^{\mathrm{ns}}$ & $5.29^{* *}$ & $3.75^{*}$ & $8.27^{* *}$ & $1.27^{\mathrm{ns}}$ & $1.40^{\mathrm{ns}}$ & $0.05^{\mathrm{ns}}$ & $4.11^{*}$ \\
\hline Gypsum & $0.05^{\mathrm{ns}}$ & $1.63^{\mathrm{ns}}$ & $2.06^{\mathrm{ns}}$ & $26.66^{\mathrm{ns}}$ & $5.33^{* *}$ & $9.89^{* *}$ & $0.05^{\mathrm{ns}}$ & $2.92^{* *}$ & $0.99^{\text {ns }}$ & $1.55^{\mathrm{ns}}$ \\
\hline Phosphorus & $0.63^{\mathrm{ns}}$ & $0.37^{\mathrm{ns}}$ & $0.31^{\mathrm{ns}}$ & $2.48^{\mathrm{ns}}$ & $3.59^{*}$ & $1.73^{\mathrm{ns}}$ & $5.84^{* *}$ & $0.74^{\mathrm{ns}}$ & $0.74^{\mathrm{ns}}$ & $0.40^{\text {ns }}$ \\
\hline Gypsum x Phosphorus & $0.55^{\mathrm{ns}}$ & $0.46^{\mathrm{ns}}$ & $0.74^{\mathrm{ns}}$ & $1.17^{\mathrm{ns}}$ & $1.72^{\mathrm{ns}}$ & $1.80^{\mathrm{ns}}$ & $1.52^{\mathrm{ns}}$ & $2.08^{\mathrm{ns}}$ & $0.54^{\mathrm{ns}}$ & $1.47^{\mathrm{ns}}$ \\
\hline \multicolumn{11}{|c|}{ Polynomial Regression } \\
\hline Equation & $\mathrm{N}$ & $P$ & $\mathrm{~K}$ & $\mathrm{Ca}$ & $\mathrm{Mg}$ & $\mathrm{S}$ & $\mathrm{Zn}$ & $\mathrm{Mn}$ & $\mathrm{Fe}$ & $\mathrm{Al}$ \\
\hline Linear Reg. & $0.02^{\mathrm{ns}}$ & $1.92^{\mathrm{ns}}$ & $2.29^{\mathrm{ns}}$ & $102.51^{* * *}$ & $18.46^{* * *}$ & $36.38^{* *}$ & $0.01^{\mathrm{ns}}$ & $11.09^{* *}$ & $0.19^{\mathrm{ns}}$ & $3.15^{\mathrm{ns}}$ \\
\hline Quadratic Reg. & $0.13^{\mathrm{ns}}$ & $1.56^{\mathrm{ns}}$ & $0.27^{\mathrm{ns}}$ & $2.93^{\mathrm{ns}}$ & $2.06^{\mathrm{ns}}$ & $2.44^{\mathrm{ns}}$ & $0.08^{\mathrm{ns}}$ & $0.55^{\text {ns }}$ & $0.86^{\mathrm{ns}}$ & $1.84^{\mathrm{ns}}$ \\
\hline
\end{tabular}

$* *$ Significant at $1 \%$ probability $(\mathrm{p}<0.01)$. ${ }^{*}$ Significant at $5 \%$ probability $(0.01=<\mathrm{p}<0.05) .{ }^{\mathrm{ns}}$ not significant $(\mathrm{p}>=0.05)$. 
The applied gypsum doses did not vsignificantly affect the corn $\mathrm{N}$ content. This result agrees with those obtained by Caires et al. (2011) that evaluated the gypsum effects on corn nutrition and yield and did not observe the effect of this product on the corn $\mathrm{N}$ content. The $\mathrm{Mg}$ and $\mathrm{K}$ contents decreased with increases in the gypsum doses (Figure 4A and 4B), and indicated that high doses of gypsum reduced the concentration of these elements in the corn leaf. This behavior was similar to that observed in soybean leafs and is explained by the same reasons.

The reduction in $\mathrm{K}$ levels that was observed in the present study led to an increase in the N-K ratio and made it adverse for crop development (Figure 4F). It should be noted that the $\mathrm{K}$ leaf contents are in the range that are considered adequate for the corn crop as indicated by Martinez, Carvalho and Souza (1999). However, the $\mathrm{N}$ contents exceeded the level that is considered as adequate.

The $\mathrm{Ca}$ and $\mathrm{S}$ adjusted to positive linear equations based on the gypsum doses. Their corn leaf contents increased with increases in the gypsum doses (Figure 4C and 4D). The increase in foliar contents of these elements was expected since this corrective is a source of these nutrients. This result agreed with those obtained by Caires et al. (1999) in which it was observed that an increase of in S leaf content of corn crop was observed with gypsum application.

Additionally, Mn contents also increased with the application of gypsum doses (Figure 4E). The increase in corn leaf tissue follows the same explanation reported in the case of the soybean crop, which is related to the residuals of the element in agricultural gypsum.
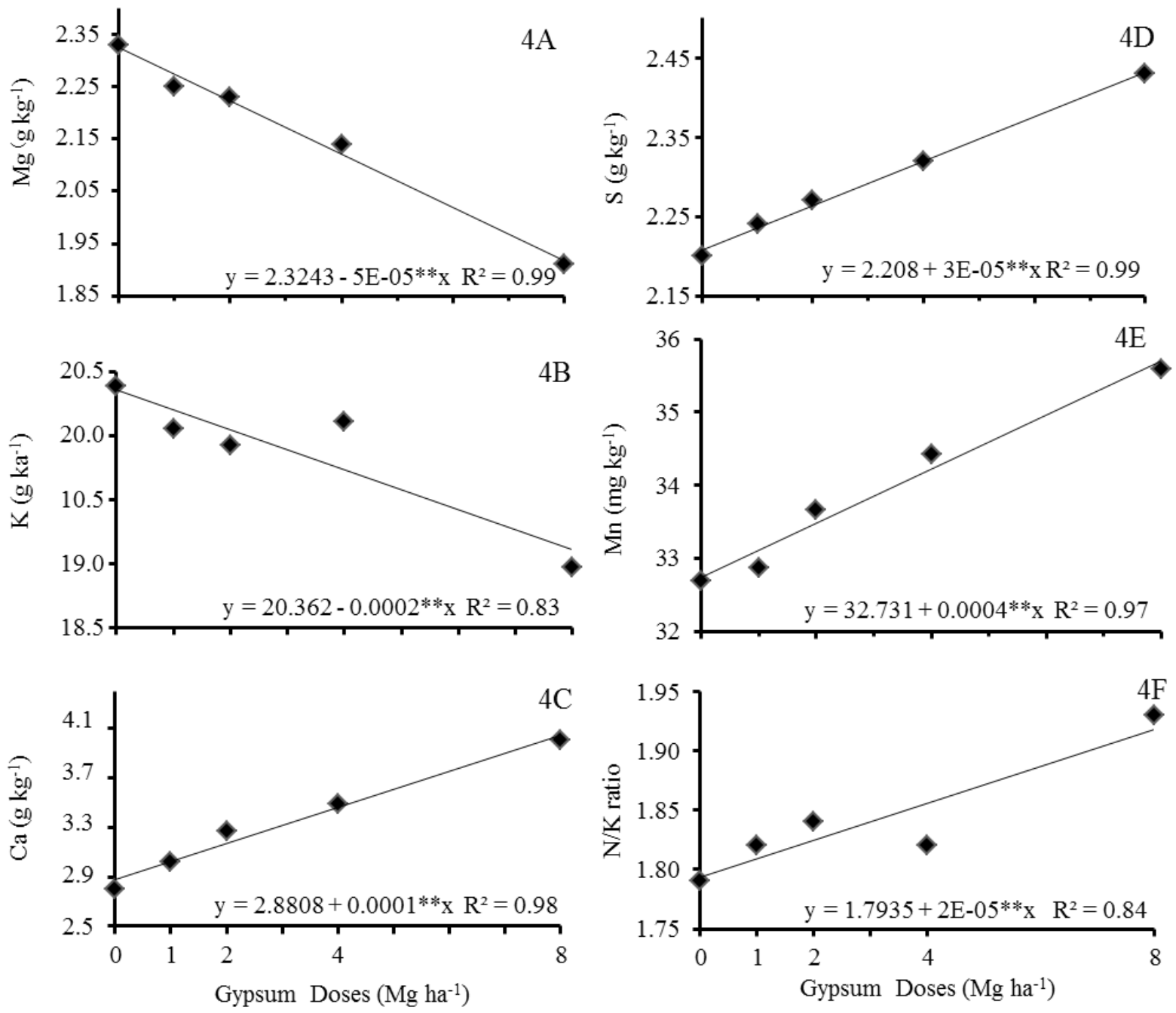

Figure 4. Foliar contents of Mg (A); K (B); Ca (C) S (D); Mn (E), and NK ratio (F) of corn crop based on gypsum doses (**Significant at $1 \%$ probability). 
With respect to the morphological components of corn, and the yield and its components, interaction between gypsum and phosphorus were not observed (Table 6). A significant difference was observed for the $\mathrm{P}_{2} \mathrm{O}_{5}$ doses only for ear length (EL), number of rows (NR), and number of grains per ear (NGE). The treatments that received $40 \mathrm{~kg} \mathrm{ha}^{-1}$ and $80 \mathrm{~kg} \mathrm{ha}^{-1}$ of $\mathrm{P}_{2} \mathrm{O}_{5}$ exhibited higher values for variables EL, NR, and NGE when compared to the treatment that did not receive phosphate fertilization (Table 6).
In the treatments in which phosphorus was not applied, the soil provided this nutrient to the plants. However, the relative absorption of $\mathrm{P}$ from soil and fertilizer may differ as a function of the plant type and stage of development (GRANT et al., 2001). Results with respect to wheat indicated that the phosphorus absorption rate from the soil increased during the growth period from four to six weeks and that soil phosphorus increased with an expansion in the volume of the roots.

Table 6. Summary of variance analysis: block, gypsum, phosphorus, and its interactions and means related to the $\mathrm{P}$ doses for the following: leaf area index (LAI), SPAD index (SPAD), dry plant mass (DM), final plant population (PP), ear length (EL), ear number of rows (NR), number of grains per ear (NGE), number of ears per hectare (NE), mass of a thousand grains (MTG), and grain yield (YIE).

\begin{tabular}{|c|c|c|c|c|c|c|c|c|c|c|}
\hline Variation Causes & LAI & SPAD & DM & $\mathrm{PP}$ & EL & NR & NGE & NE & MTG & YIE \\
\hline Block & $0.10^{\mathrm{ns}}$ & $14.95^{* *}$ & $10.52^{* *}$ & $6.99^{* *}$ & $2.41^{\mathrm{ns}}$ & $1.19^{\mathrm{ns}}$ & $1.58^{\mathrm{ns}}$ & $3.04^{*}$ & $1.44^{\mathrm{ns}}$ & $3.99^{\text {ns }}$ \\
\hline Gypsum & $1.78^{\mathrm{ns}}$ & $0.51^{\mathrm{ns}}$ & $0.03^{\text {ns }}$ & $0.67^{\mathrm{ns}}$ & $1.52^{\mathrm{ns}}$ & $0.64^{\mathrm{ns}}$ & $0.40^{\text {ns }}$ & $0.41^{\mathrm{ns}}$ & $1.55^{\mathrm{ns}}$ & $0.14^{\mathrm{ns}}$ \\
\hline Phosphorus & $1.10^{\mathrm{ns}}$ & $0.28^{\mathrm{ns}}$ & $0.06^{\mathrm{ns}}$ & $1.73^{\mathrm{ns}}$ & $8.18^{* *}$ & $6.55^{* *}$ & $11.29^{* *}$ & $1.00^{\mathrm{ns}}$ & $0.64^{\mathrm{ns}}$ & $0.89^{\mathrm{ns}}$ \\
\hline Gyspsum x P & $0.20^{\mathrm{ns}}$ & $0.82^{\mathrm{ns}}$ & $0.31^{\mathrm{ns}}$ & $0.89^{\mathrm{ns}}$ & $0.73^{\mathrm{ns}}$ & $1.62^{\mathrm{ns}}$ & $1.90^{\mathrm{ns}}$ & $0.78^{\mathrm{ns}}$ & $1.36^{\mathrm{ns}}$ & $0.81^{\mathrm{ns}}$ \\
\hline \multicolumn{11}{|c|}{ Polynomial Regression } \\
\hline Equation & LAI & SPAD & $\mathrm{DM}$ & PP & $\mathrm{EL}$ & NR & NGE & $\mathrm{NE}$ & MTG & YIE \\
\hline Linear Reg. & $5.26^{*}$ & $0.73^{\mathrm{ns}}$ & $0.01^{\mathrm{ns}}$ & $1.84^{\mathrm{ns}}$ & $0.08^{\mathrm{ns}}$ & $1.24^{\mathrm{ns}}$ & $0.70^{\text {ns }}$ & $0.46^{\mathrm{ns}}$ & $2.62^{\mathrm{ns}}$ & $0.40^{\mathrm{ns}}$ \\
\hline Quadratic Reg. & $1.74^{\mathrm{ns}}$ & $1.20^{\mathrm{ns}}$ & $0.01^{\mathrm{ns}}$ & $0.09^{\text {ns }}$ & $0.62^{\mathrm{ns}}$ & $0.19^{\mathrm{ns}}$ & $0.84^{\mathrm{ns}}$ & $0.61^{\mathrm{ns}}$ & $0.06^{\mathrm{ns}}$ & $0.03^{\mathrm{ns}}$ \\
\hline Phosphurus & LAI & SPAD & $\mathrm{DM}$ & $\mathrm{PP}$ & EL & NR & NGE & $\mathrm{NE}$ & MTG & YIE \\
\hline $0 \%$ & $4.54 \mathrm{a}$ & $1040.50 \mathrm{a}$ & $5807.96 \mathrm{a}$ & $2.59 \mathrm{a}$ & $15.02 \mathrm{~b}$ & $16.00 \mathrm{~b}$ & $506.47 \mathrm{~b}$ & $23.50 \mathrm{a}$ & $285.36 \mathrm{a}$ & $6719.97 \mathrm{a}$ \\
\hline $50 \%$ & $4.66 \mathrm{a}$ & $1048.98 \mathrm{a}$ & $5930.16 \mathrm{a}$ & $2.58 \mathrm{a}$ & $16.01 \mathrm{a}$ & $16.43 \mathrm{a}$ & $550.07 \mathrm{a}$ & $23.35 \mathrm{a}$ & $282.63 \mathrm{a}$ & $7181.00 \mathrm{a}$ \\
\hline $100 \%$ & $4.76 \mathrm{a}$ & $1043.26 \mathrm{a}$ & $5873.83 \mathrm{a}$ & $2.49 \mathrm{a}$ & $15.66 \mathrm{a}$ & $16.44 \mathrm{a}$ & $537.43 \mathrm{a}$ & $22.55 \mathrm{a}$ & $289.84 \mathrm{a}$ & $6895.00 \mathrm{a}$ \\
\hline MSD & 0.37 & 27.21 & 855.09 & 0.16 & 0.60 & 0.33 & 22.92 & 1.75 & 15.67 & 846.34 \\
\hline $\mathrm{VC} \%$ & 10.40 & 3.39 & 18.97 & 8.26 & 5.05 & 2.64 & 5.62 & 9.85 & 7.14 & 15.90 \\
\hline
\end{tabular}

$* *$ Significant at $1 \%$ probability $(\mathrm{p}<0.01) . *$ Significant at $5 \%$ probability $(0.01=<\mathrm{p}<0.05)$. ${ }^{\mathrm{ns}}$ not significant $(\mathrm{p}>=0.05)$. The means followed by the same letter do not differ statistically by the Tukey test at $5 \%$ probability.

A potential explanation for inferior results at zero phosphorus doses is the occurrence of a nutrient deficiency during ear formation (V6 and V7) as a function of the difference in the relative phosphorus absorption from the soil when compared with that from the fertilizer. This deficiency of this element in the plant may decrease the size of the ear and consequently decrease grain number per ear (GRANT et al., 2001). However, these production components differences were insufficient to promote an increase in grain yield.
With respect to the gypsum doses, it was possible to adjust linear regression equations for the leaf area index (Figure 5). It is observed that an increase in gypsum doses decreased leaf area index values. According to Fancelli (1994), photosynthetic rate reduction after flowering may be caused by drought, excess rainfall, prolonged cloudiness, and an unfavorable $\mathrm{N}$ - $\mathrm{K}$ ratio in which excess nitrogen typically contributes to the imbalance.

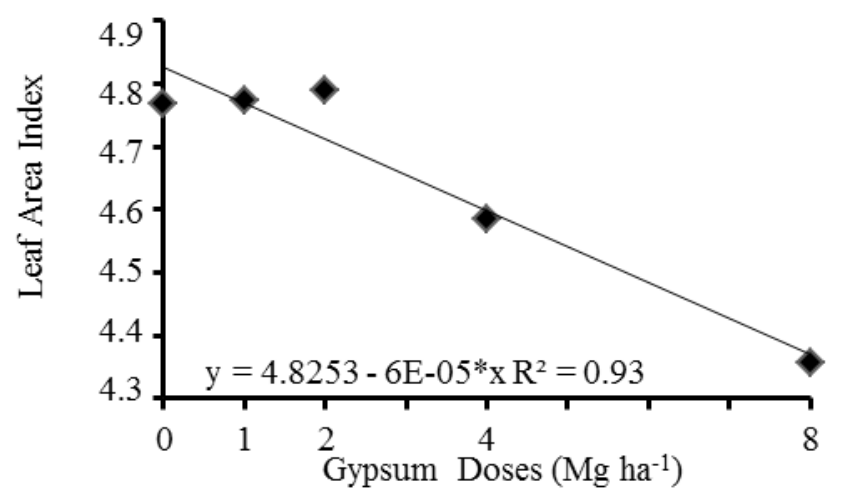

Figure 5. Leaf area index based on gypsum doses. *Significant at 5\% probability. 
Leaf $\mathrm{N}$ contents did not change based on the applied gypsum doses (Table 5). However, the K leaf content decreased linearly with increases in the gypsum doses (Figure 4B). This reduction in $\mathrm{K}$ contents results in an increase in the $\mathrm{N}-\mathrm{K}$ ratio and makes it adverse for the development of crops as previously mentioned.

It is important to note that the $\mathrm{K}$ leaf levels observed in the study when compared to the results obtained by Martinez, Carvalho and Souza (1999) are in the range considered adequate for the corn crop although the $\mathrm{N}$ contents are excessive. This justifies the negative behavior of the leaf area index with respect to an increase in gypsum doses.

The expected effect of an improvement in the distribution of soil profile cations and higher $\mathrm{Ca}$ and $\mathrm{S}$ concentrations in depth promoted by the gypsum are insufficient to provide increases in corn yield in the first cultivation year.

This lack of response in corn crop yield based on gypsum doses could be related to the good rainfall distribution during crop development (Figure 1) and the adequate soil nutrient levels for corn development and yield (Table 1).

\section{CONCLUSIONS}

The soil and climate conditions in which the experiment was conducted indicated that the phosphorus doses increase $\mathrm{Mg}$ foliar contents in soybean and corn. The application of gypsum reduces $\mathrm{Mg}$ and $\mathrm{K}$ foliar contents and increases $\mathrm{Ca}$, $\mathrm{Z}$, and $\mathrm{Mn}$ contents in the two crops. Gypsum increases the SPAD index in soybean plants. The increase in the gypsum doses leads to a $\mathrm{N}$ - K ratio unbalance in corn leaves and reduces the crop leaf area. Doses of $\mathrm{P}$ and gypsum do not influence yields of soybean and corn crops.

\section{REFERENCES}

BROCH, D. L. et al. Influência no Rendimento de Plantas de Soja pela Aplicação de Fósforo, Calcário e Gesso em um Latossolo Sob Plantio Direto. Revista Ciências Exatas e Naturais, Guarapuava, v. 10, n. 2, p. 211-220, 2008.

CAIRES, E. F. et al. Alterações de características químicas do solo e resposta da soja ao calcário e gesso aplicados na superfície em sistema de cultivo sem preparo do solo. Revista Brasileira de Ciência do Solo, Viçosa, v. 22, n. 1, p. 27-34, 1998.

CAIRES, E. F. et al. Produção de milho, trigo e soja em função das alterações das características químicas do solo pela aplicação de calcário e gesso na superfície, em sistema de plantio direto. Revista
Brasileira de Ciência do Solo, Viçosa, v. 23, n. 2, p. 315-327, 1999.

CAIRES, E. F. et al. Alterações químicas do solo e resposta da soja ao calcário e gesso aplicados na implantação do sistema plantio direto. Revista Brasileira de Ciência do Solo, Viçosa, v. 27, n. 2, p. 275-286, 2003.

CAIRES, E. F. et al. Surface application of gypsum in low acidic Oxisoil under no-till cropping system. Scientia Agricola, Piracicaba, v. 68, n. 2, p. 45-53, 2011.

CAIRES, E. F.; JORIS, H. A. W.; CHURKA, S. Long-term effects of lime and gypsum additions on no-till corn and soybean yield and soil chemical properties in southern Brazil. Soil use and Management, Weinheim, v. 27, n. 1, p. 45-53, 2011.

EMPRESA BRASILEIRA DE PESQUISA AGROPECUÁRIA - EMBRAPA. Sistema brasileiro de classificação de solos. 2 . ed. Rio de Janeiro, RJ: Embrapa - SPI, 2006. 286 p.

FANCELLI, A. L. Milho e feijão: Elementos para manejo em agricultura irrigada. Piracicaba, SP: Departamento de agricultura/ESALQ/USP, 1994. 14 p.

GELAIN, E. et al. Fixação biológica de nitrogênio e teores foliares de nutrientes na soja em função de doses de Molibdênio e gesso agrícola. Ciência e Agrotecnologia, Lavras, v. 35, n. 2, p. 259-269, 2011.

GRANT, C. A. et al. A importância do fósforo no desenvolvimento inicial da planta. 95. ed. Piracicaba, SP: Informações Agronômicas Potafos, 2001. 16 p.

MALAVOLTA, E. Manual de nutrição mineral de plantas. São Paulo, SP: Agronômica Ceres, 2006. $638 \mathrm{p}$.

MALAVOLTA, E.; VITTI, G. C.; OLIVEIRA, S. A. Avaliação do estado nutricional das plantas: princípios e aplicações. 2. ed. Piracicaba, SP: POTAFOS, 1997. 319 p.

MARTINEZ, H. E. P.; CARVALHO, J. G.; SOUZA, R. B. Diagnose foliar. In: RIBEIRO, A. C.; GUIMARÃES, P. T. G.; ALVAREZ V. V. H. (Eds.). Recomendações para o uso de corretivos e fertilizantes em Minas Gerais. 5a Aproximação. 20. ed. Viçosa: UFV, 1999. cap. 17, p. 143-168.

MATTIELlO, E. M. et al. Produção de matéria seca, crescimento radicular e absorção de cálcio, fósforo e alumínio por coffea canephora e coffea arabica sob 
influência da atividade do alumínio em solução. Revista Brasileira de Ciência do Solo, Viçosa, v. 32, n. 1, p. 425-434, 2008.

MODA, L. R. et al. Gessagem na cultura da soja no sistema de plantio direto com e sem adubação potássica. Revista Agro@mbiente On-line, Boa Vista, v. 7, n. 2, p. 129-135, 2013.

MUNER, L. H. et al. Disponibilidade de zinco para milho em resposta à localização de fósforo no solo.

Revista Brasileira de Engenharia Agrícola e Ambiental, Campina Grande, v. 15, n. 1, p. 29-36, 2011.

NAVA, G. et al. Soil composition and nutritional status of apple as affected by long-term application of gypsum. Revista Brasileira de Ciência do Solo, Viçosa, v. 36, n. 1, p. 215-222, 2012.

NEIS, L. et al. Gesso agrícola e rendimento de grãos de soja na região do sudoeste de Goiás. Revista Brasileira de Ciência do Solo, Viçosa, v. 34, n. 2, p. 409-416, 2010.

NORA, D. D. et al. Alterações químicas do solo e produtividade do milho com aplicação de gesso combinado com calcário. Magistra, Cruz das Almas, v. 26, n. 1, p. 1-10, 2014.

OLIVEIRA, I. P. et al. Efeitos de fontes de cálcio no desenvolvimento de gramíneas solteiras e consorciadas. Ciência e Agrotecnologia, Lavras, v. 33, n. 2, p. 592-598, 2009.

PAULETTI, V. et al. Efeitos em longo prazo da aplicação de gesso e calcário no sistema de plantio direto. Revista Brasileira de Ciência do Solo, Viçosa, v. 38, n. 2, p. 495-505, 2014.

PAVINATO, P. S.; CERETTA, C. A. Fósforo e potássio na sucessão trigo/milho: épocas e formas de aplicação. Ciência Rural, Santa Maria, v. 34, n. 6, p. 1779-1784, 2004.

RAMPIM, L. et al. Atributos químicos de solo e resposta do trigo e da soja ao gesso em sistema semeadura direta. Revista Brasileira de Ciência do Solo, Viçosa, v. 35, n. 5, p. 1687-1698, 2011.

RITCHEY, K. D.; SILVA, S. E.; COSTA, V. F. Calcium deficiency in clayey B horizons of savannah Oxisols. Soil Science, New Brunswick, v. 133, n. 6, p. 378- 382, 1982.

ROSOLEM, C. A.; ASSIS, J. S.; SANTIAGO, A. D. Root growth and mineral nutrition of corn hybrids as affected by phosphorus and lime. Communications in Soil Science and Plant Analysis, New York, v 25, n. 13-14, p. 2491-2499, 1994.

SÁVIO, F. L. et al. Calagem e gessagem na nutrição e produção de soja em solo com pastagem degradada. Revista Agrotecnologia, Anápolis, v. 2, n. 1, p. 19-31, 2011.

SORATTO, R. P.; CRUSCIOL, C. A. C. Atributos químicos do solo decorrentes da aplicação em superfície de calcário e gesso em sistema plantio direto recém-implantado. Revista Brasileira de Ciência do Solo, Viçosa, v. 32, n. 2, p. 675-688, 2008

SOUSA, D. M. G.; LOBATO, E. Calagem e adubação para culturas anuais e semiperenes. In: (Eds.). Cerrado: correção do solo e adubação. 2. ed. Brasília: Embrapa Informação Tecnológica, 2004. cap. 12, p. 283-315.

VENDRAME, P. R. S. et al. Disponibilidade de cobre, ferro, manganês e zinco em solos sob pastagens na Região do Cerrado. Pesquisa Agropecuária Brasileira, Brasília, v. 42, n. 6, p. 859 -864, 2007.

ZANDONÁ, R. R. et al. Gesso e calcário aumentam a produtividade e amenizam o efeito do déficit hídrico em milho e soja. Pesquisa Agropecuária Tropical, Goiânia, v. 45, n. 2, p. 128-137, 2015.

ZHONG, W.; SCHOBERT, C.; KOMOR, E. Transport of magnesium ions in the phloem of Ricinus communis L. seedlings. Planta, Freiburg, v. 190, n. 1, p. 114-119, 1993. 